\title{
I Don't Understand What They Speak: Photovoice of Indonesian Higher Education Students
}

\author{
Tri Susmita Sari ${ }^{1}$, Malikhatun Naimah ${ }^{2}$, Ardiana Wafda Martalina ${ }^{3}$, Lisa lin \\ Arjiani 4 \\ 1,2,3,4 Tadris Bahasa Inggris, Fakultas Tarbiyah, Institut Agama Islam Negeri Kudus, \\ Kudus, Indonesia
}

\begin{tabular}{|l|l|l|l|}
\hline Contact: & Tri Susmita Sari & $\bigotimes$ & mitasarii08@gmail.com \\
\hline
\end{tabular}

\begin{abstract}
This study discusses the problems and causes experienced by higher education students when listening to everything spoken by native speakers. They find it very difficult to understand speech spoken directly or from audio learning English. This makes them feel restless and uncomfortable in listening lessons and exams on campus while these subjects are very important for them as students. This study uses the photovoice methods in examining the problems experienced by several higher education students, so that it will focus more on the factors causing the problems and the problems experienced. The study was based on the experience of an English major in education. It involved four English speaking students and audio speakers. The study suggests that a parable occurred when an English education student understood the words of native speakers and audio speakers. It provides input to everyone associated with the study of English to recognize problems in understanding native speakers.
\end{abstract}

\author{
KEYWORDS: \\ Photovoice, Native \\ Speaker, English, Higher \\ Education
}

\section{Introduction}

The language of English has been going through a twin system of globalization and nativization. English is the right language to become an international lingua franca and a language throughout the world, this is due to the globalization of the English language, while the nativization of English diversifies it into styles of English, that is, The world Englishes (Xu, 2018). English must be used as a subject in every education, usually can start in elementary school, junior high schools, and senior high schools. Not only that. Many universities in Indonesia have English majors in their study 
programs to improve the ability of prospective successful people to master English. In mild of the more and more international nature of education and the ensuing multicultural and multilingual student populations that have come to be not unusual in higher education (Murray, 2011). However, not all of them can easily understand the materials they have been taught, even basic English. One of them is listening. For Indonesians, listening to the pronunciation spoken by fellow Indonesians can still understand a little. However, suppose a native speaks the English pronunciation. In that case, it will feel a little difficult to understand, such as audio learning English given by a teacher to students, broadcast programs on television and radio, even to take the TOEFL and IELTS tests, they have to repeat the test because their TOEFL score is very low, this happens because they do not understand what a native speaker is saying, so they feel listening is part of learning English which is very difficult for them. We look at factors to the want to apprehend context through more than one strategy and the capacity of photovoice as a method to mediate verbal exchange and participation in studies for groups (Ha \& Whittaker, 2016).

Some research about photovoice has been taken by Wass et al., (2019) that Higher Education (HE) studies regularly attract on several qualitative studies approaches. However, a few techniques evolved in different fields are underutilized in HE studies, even though they may be of remarkable use for answering specific sorts of studies questions or regarding students extra actively with inside the studies process. (Martinez et al., 2019) The paper demonstrates that through which includes participatory elements (in this situation, photovoice) has the ability to operationalize Appadurai's perception of the 'proper to studies' amongst undergraduates. Using data, together with processes, observations, workshops, interviews, and visible narratives from a participatory photovoice project, the findings spotlight how methodological plurality creates an area for domestically and applicable understanding production, challenging epistemic obstacles and 
fostering human improvement the studies participants. (Ronzi et al., 2016) Urbanization and populace ageing have contributed to recognizing towns as essential settings for wholesome ageing. This paper considers opportunities, demanding situations, and answers to the use of photovoice techniques to explore how people understand their towns and their contribution to their health. It makes a specialty of older people's experiences - appreciation and social inclusion, withinside the context of a community - primarily based on totally participatory studies. However, in research about photovoice, especially higher education students, many studies discuss photovoice and higher education students. However, research on students' lack of understanding of learning English related to hearing and understanding what is said by a native speaker is still very little, even difficult to find. Therefore, this article aims to explore Indonesian higher education students while they encounter problems with understanding various types of audios in English spoken by native speakers. This research will be a different study from the others because researchers rarely study it.

This material is very interesting to study because it discusses the reasons why higher education students find it difficult to understand what a native speaker is saying. There are so many complaints from students that are still happening in the world of education, one of which is the difficulty in speaking English, especially in terms of listening to native speakers, while in all worlds of education and in the world of work, English language abilities are very much needed. Meanwhile, when they try to learn it they despair and feel they don't want to learn this language anymore, but future demands force them, one of which is the requirement to be accepted in a dream campus or in a dream company, they must follow the stages of selection, one of which is a listening test. It is affordable to think that local speakers advanced through transference from the local language, at the analogy of the connection of the phrase's language and speaker, and that 
this transference took place especially in English, given the problem of translating local speakers into even carefully associated European languages (Joseph, 2016). With this research, the researcher hopes to provide information related to the causes of the problems and real solutions to higher education students' complaints. Therefore, this research can positively impact the world of scientific development, especially in the world of education.

\section{Native vs Nonnative: How Indonesian Understand the Speaking}

List the key tenets of "nativeness" as follow: (a) childhood acquisition of the language, (b) comprehension and production of idiomatic varieties of the language, (c) understanding regional and social variations among the language, and (d) competent production and comprehension of fluent, spontaneous discourse (Davies, 2004). Given that each of these tenets, however, the first could also be non-inheritable or learned post-childhood, one might argue that the sole changeless distinction between verbalizer and nonnative speaker of a language is childhood acquisition (Walkinshaw \& Oanh, 2014). Yet the native or nonnative distinction permeates English language teaching (ELT) ideology (Arva \& Medyes, 2000, Mousu \& Liurda, 2008), perpetuating difference between the 2 teams (Canagarajah, 1999).At least forty studies are conducted of the linguistic and informal changes created by native speakers of language exploitation for communication with nonnative speakers. The modifications generally end in ungrammatical speech. Generally, however, they serve to produce well-formed input, a kind of linguistic and conversational cocoon for the neophyte seconds language acquirer. Although qualitative and quantitative differences, most of the findings hold across age groups, social categories, and settings. In creating adjustments described, native speakers seem to be reacting to not one, but to a mix of factors. These embrace the linguistics characteristics and comprehensibility of the nonnative's interlanguage, but particularly his or 
her apparent comprehension of what the verbalizer is speech communication. The changes seem to be necessary for second language acquisition in that beginners appear unable to amass from unrestricted native speaker input. In summary, it has been argued that native speaker's react to a mix of things after they create linguistic/conversational adjustment to nonnative speakers, these embrace the understandability of nonnative speakers language linguistics characteristics, and the nonnative speakers apparent comprehension of what the native speaker is saying in sure restricted circumstances, primary initial reactions to little interlanguage samples, the nonnative speakers comprehensibility and physical look could also be a lot of influential (Long, 1983), as we tend to shall see below. The gift study adopts the terms native associate in nursing nonnative: how Indonesian perceive the speaking focus of this research.

Perceive has an epistemological aim like-minded to the field. Understanding refers to grasping an informative relationship among the body of information. Two varieties of understanding will be distinguished: ontological and ontic. Ontological understanding is background activity through that perception and thinking happen. Thus, ontological understanding could be a matter of agent's awareness and experiential engagement with their environment. In short, it is one's creating sense of their situation. Over this background, ontic understanding can be outlined as coherent by an aware agent through metaphysics understanding (Gorichanaz, 2020). All (in a during in Associate in Nursing exceedingly in a very), the idea of understanding provides an account for a way bodily experience, recorded data, and different varieties of information will contribute epistemically to concert. While students and instructors may utilize "understanding" in an informal manner, the term has been formally outlined in many ways. Dawes focuses on understanding because of the ability to examine the "meaning of the thing". Including what causes it, how it works, or how it is regarding other things (Dewey, J. 1933). 
The concept of understanding seems at first at the purpose of interaction between the philological, hermeneutical, and theologicalphilosophical traditions. The concept of understanding already appears as a philosophical term within the language of the mystics, starting type (Augustine), for whom it had a broader significance than simply seeing. The Kantian idea of understanding is afterwards reappropriated quite originally by a human who, by stressing the bounds of the human understanding of the book of nature. It develops the concept of historical understanding, grasped as situating oneself in the past that presupposes an understanding of presupposed an understanding of this and foreseeing of the future. One of the foremost relevant philosophical issues that continue to be after Ludwing Wittgenstein and Gadamer is the relation between understanding and interpretation. Not all understanding is decoding, and wherever there is understanding, there is not interpreting and translating, but simply "speech" (Di Cesare, 2015).

\section{Speaking Class in Indonesian Context}

English is an international language. It is a language used to communicate between countries. The ability to speak English is vital to the future. To prepare for generations to come, junior high school in Indonesia must make English a must be used as a must. Public and private schools have the same value, making English compulsory (Krishnakumar, 2004). At the junior high, English-speaking lessons were given greater emphasis. Students get the science on speaking English in class. Teachers have prepared materials to develop student skills in speaking English. In addition to obtaining material, students are also motivated to learn to speak English outside of class, using the computer and mobile devices, and students can access the science of English-speaking more widely and globally (Alotumi, 2020). The selfmotivated student to learn English is a confident student of his or her ability to speak English. The interest in learning English in Indonesia was low. 
Children in Indonesia tend to underestimate English lessons. So any students who have English language skills should be developed by practicing English skills in everyday life, training English skills by communicating with foreigners, would thus be able to hone the student's English skills (Alotumi, 2021)

When completing a task and learning a high score, students will feel proud. High grades can make students more eager to learn English, which suggests that their skills in English are increasing, and students will be able to determine the extent to which they are developing the English language (Uztosun, 2020). Accordingly, in an educational context, SRL refers to university students' self-initiation of making ultimate situations for his or her gaining knowledge through controlling influencing elements and overcoming interfering obstacles (Seli \& Dembo, 2020). Though they are most important in English, many Yemeni university college students find it hard to talk English fluently (Al-Tamimi et al., 2020). Though they are most important in English, many Yemeni university college students find it hard to talk English fluently (Al-Tamimi et al., 2020). Regulation of studying surroundings includes students' tries to conquer studying interruptions, nuisances, and stumbling blocks that existed within the studying surroundings via looking for different methods to fine-song their undertaking studying and practicing (Pintrich, 2004; Yan et al., 2020).

\section{Research Methodology}

\section{Photovoice}

Photovoice, a qualitative participatory studies technique that can identify, represent, and decorate the network through a selected photograph technique, is applied. This technique builds on ethnographic studies, feminist story and documentary photography. In the photovoice process, character network contributors are supplied cameras after which precipitated to capture visible representations in their day by day lives to 
benefit perception into formerly invisible practices and belongs of the network, that may assist the network to higher to have interaction in crucial speak approximately the issues and possibilities it is the individual face (Horii et al., 2021). Photovoice, typically related to participatory movement research (PAR), happens while participatory researchers use images to provide new insights and views closer to making improvements (Kelly, Lee, Ray, \& Kandaurova, 2018; Wang \& Burris, 1997). In many instances, the images are supplemented with narrative or elicit information in an imageelicitation method (Becke \& Bongard, 2018; Copes, Tchoula, Brookman, \& Ragland, 2018). (Ciolan \& Manasia, 2017a) State that visual techniques utilized in academic research, consisting of photovoice, present a medium for pupil interplay and engagement: photovoice does now no longer simplest offer a possibility to look at pupil studying however additionally lets in the researcher to look at pupil studying however additionally lest in the researcher to look at pupil mindsets. photovoice provides a medium for student interaction and engagement: photovoice provides an opportunity to observe student learning and allows the researcher to observe student mindsets. Behrendt and Machtmes (2016) use photovoice of their have a look at as an assessment device for instructors to higher apprehend pupil needs, revel in, and private growth; the look at demonstrates the usage of photovoice in a casual learning knowledge of putting to gauge scholar mastering and revel in. demonstrates using photovoice to study preservice instructor perceptions and revel in at the same time as coaching pupil for non-stop development of the instructor education program (PETE). Photovoice is utilized in different disciplines, including healthcare, to perceive gaps or obstacles in network-extensive participation; humans with accidents face numerous environmental challenges to take part and interact with inside the network, makes use of photovoice to observe elements that impact network engagement and participation of humans with spinal wire accidents (Kotla et al., 2021). 
Photovoice Methodology (PVM) gives studying researchers numerous key methodological advantages. First, PVM presents get right of entry to settings and subjective reports which can be hard to get entry to in retrospect or observational studies. Second, PVM urged topics to interact withinside the study's method and immediately given facts collection. For example, images are taken at some stage in real-lifestyles studies, for that reason decreasing bias due to retrospective reporting. Third, PVM offers to get right of entry to mastering reviews of an extensive wide variety of topics and helps in-depth qualitative studies.

In PVM research, topics are requested to take pictures at some point of classes, homework preparation, and collaborative workings in individual and personal settings. This approach provides getting entry to private reports that might rarely be, if ever, to the researcher himself or herself. However, the researcher's insertion can also also reason modifications in getting to know patterns, particularly in cognitive and regulatory strategies (Richardson, 2013). Another benefit of PVM is that it offers admission to data of which members might not be aware. Magolda (2001, p. 530, as quoted in Gibels et al., 2014, p.297). Photovoice emphasizes the expression use of images and narrative. By providing access to an internal perspective that is not often accessible to the researcher, PVM lets the researcher sharpen his or her selection of and interpretation of phenomena and experiences. Moreover, as previously argued, the focus of PVM, which is based on an active participatory methodological concept, is on subjects. In this sense, in addition to being involved in the process, participants grow to be co-researchers during data analysis. The focus on instantaneous images reflecting the subject states of mind may provide support not only from a methodological framing perspective, but it may also facilitate the whole processes of those involved who are accustomed to operating in white images, pictures, and so on, in all aspects of their lives (Ciolan \& Manasia, 2017b). 


\section{Participants}

In this study, the researcher is an object of study because it contains how the researchers respond in understanding what they speak with method photovoice of Indonesian higher education. Participants in this research: MN, AWM, LIA, TSS. The player recruitment and statistics series came about between 20 June 2021 and 23 June 2021. Researchers chose this source because the source is undergraduate students in an English study program from a University in Kudus. The student still does not fully understand what the native speaker was saying, and nor what he would listen to on audio, whereas the student needed to understand what the native speaker and audio were saying. Because they are majoring in English, researchers chose that source that is thought to be consistent with the problem of the study. The study individuals were 19 college students between 20 and 21 years old. They all majored in the English program and comprised 4 second-college students and 4 females.

\section{Data Collection}

The participants have been invited to enroll in a briefing consultation on 22 June 2021, where in the studies process and cause have been introduced. The participant should decide out at this level in the event they wish. None of the participants asked to withdraw. The lead researcher then advised the students (subordinate researchers). Furthermore, on the way to use their cell phones to take pictures, with attention to moral requirements. After the briefing consultation, every scholar requested to take 3 pictures over the day. Based on or greater of the subsequent themes (1) what are the circumstances surrounding researchers when listening to native speakers and audio speech? (2) What obstacles can cause researchers not to understand native speakers and audio speech? (3) What caused researchers to find native speakers and audio sayings difficult to grasp? 
For a photo-dialogue consultation on 23 June 2021, every player certainly decided to consider one of her snapshots to share. The sharing became guided using the SHOWED questions, which every player becomes given 20 to twenty-five mins to answer. After every sharing, brief responses had been invited from the player. When all the members had completed sharing, lead researchers recommended club studies to pick out the shared snapshots that they desired to talk about in addition as a group. The cause of the sharing and dialogue became to permit the members to assign meanings to the snapshots through (Latz \& Mulvihil, 2017).

\section{Data Analysis Procedures}

The sharing and dialogue have been transcribed verbatim. To generate topics, the researchers first analyzed the facts of the usage of open coding. The content material of the transcripts changed into tested lines with the aid of using lines in a try to code that means topics (Esterberg, 2002). Focused coding changed into then implemented to broaden greater salient topics from the facts, with the aid of using reassembling the segments of topics that emerged from the open coding (Saldana, 2009). To enhance the evaluation of the facts, the researcher constantly delicate the topics with the aid of using evaluating incidents withinside the facts with different incidents, the incident with topics, and topics with different incidents, incidents with topics, and topics with different topics in the course of the coding (Glaser \& Strauss, 1967). The data analysis ended while no different topics.

\section{Findings}

\section{Fill in the main in understanding}

Being a student majoring in English education, you are taught learning materials using English, such as listening, speaking, reading, and writing. However, not a few students still feel confused in understanding the lesson, primarily listening. Problems like this should be a particular concern for 
students who have problems like this, they are students who are required to be able to understand this because it has become their obligation as a student majoring in English education. This experience is well illustrated by the photo of the vast expanse of the sky and the scenery shared by TSS students (in figure 1), who think as follows:

I want to share this picture with you because the picture expresses my thoughts when I listen to whatever native speakers say, such as learning audio, audio during listening exams, movies without subtitles, television, or radio broadcasts, and so on spoken by native speakers. In the picture there is a wide and cloudy expanse of the sky, but the sky is not completely bright and not completely dark, the sky is cloudy and underneath there is a high green mountain. As I thought when I heard the words of the native speakers, I didn't fully understand what the native speakers were saying, there were some sentences that I could understand but there were also those that confused me with what they said, even though I was a student majoring in English. Understanding native speaker speech is a requirement that I must master, because English is an international language used by all residents of the world as wide as the sky, because if I can understand the words of native speakers, I will more easily reach my high goals such as the mountains in the picture, because by understanding English, I will know the world more broadly. (Student TSS)

Several ways that can be done to improve listening skills in learning must start from within the students first, they must have a strong desire to master listening and understand what is spoken by native speakers, not only that they also must get used to listening to audio learning exercises and other audio so that their ears are more accustomed to listening to the words of native speakers. The following are the statements of higher education students in understanding the problems they are currently experiencing.

Based on the picture, I understand that the process of understanding something is not easy. Every process must have light and dark, just like my understanding in understanding the speech of a native speaker. Problems in understanding like this are usually caused by language styles and accents that are different from each country so that it 
cannot be forced for Indonesians to have the exact same pronunciation as native speakers, usually Indonesian people will find it easier to understand the pronunciation spoken by Indonesians themselves. Whereas if English is spoken by native speakers, they will feel confused and have high attention to be able to understand what they are saying. Even English itself has three different styles of language, namely British, American, and Australian so that every country is not the same in pronouncing it. (Student TSS).

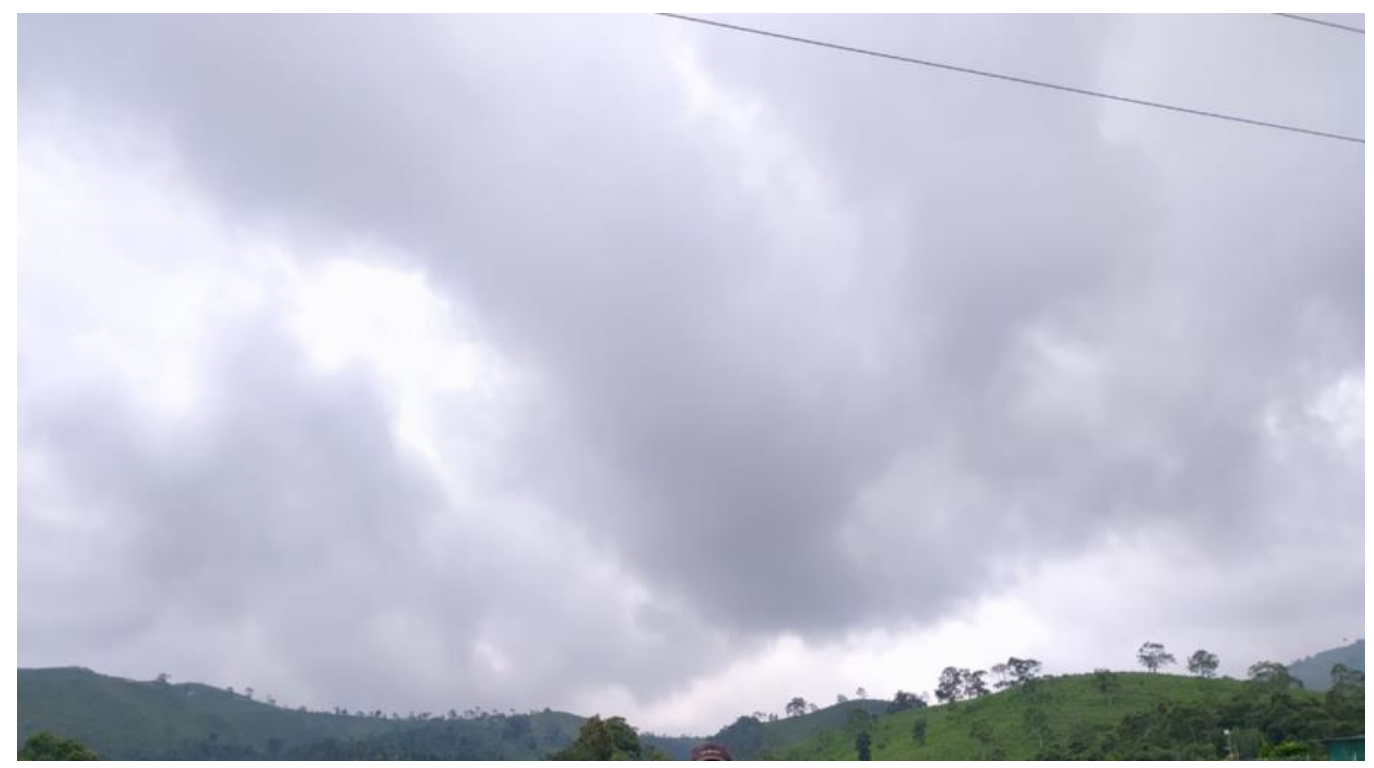

Figure1. A photograph of combination of clear and dark skies with high mountains

\section{Concussion and misapprehension of listening to native speakers and audio}

For some people wondering, what the hell do English students learn? Indeed, if you hear the English department that you have in mind to learn about grammar and vocabulary, it's true but it's not as simple as that in this department, we need to validate speaking skills the pronunciation must be correct, the ability to understand when listening, reading skills, and be taught how to write properly, according to the grammar. The four before (Speaking, Listening, Reading, and Writing) in English are conditional courses. This means that you will study this course from the beginning of the first semester to the fourth semester but with a different purpose.

For example, in semesters one and two practice from the basic, if in the first semester of speaking, the important thing is that you can speak in 
English even though the grammar is wrong. It is okay, this time you will understand. Next semester, you will learn how to argue, public speaking, and practice TOEFL or IELTS speaking, so here your listening skills must also be good, so that when there are debating courses, you can understand the words of native speakers. In this study, students majoring in English will share their experiences while studying in the English department. How these students faced semester exams and how difficult it was to study in this department when understanding the content heard from the words of native speakers and audio. This research will be presented using the illustrated photograph, as follows:

In this study, I can share my readers what was impeding my understanding and how I felt when listening to native speaker and audio. I fell as I listen to my thoughts audio as is an empty wall, as native speaking, as well as audio listening to audio, I have no idea of what native speaker or audio is delivering. I was confused when trying to capture what native speaker or audio said, and instead I could not understand the words native speaker and audio, probably because of the lack of vocabulary I was good at, because of the lack of vocabulary I was able to practice English when I was at home, or in my neighborhood in my life, and it also took me a long time to translate what native speaker and audio had offered. Life as a student must be related to lessons, exercises, assignments, mid- semester tests, end-of-semester tests, etc. If I am asked (1) How do I feel when I do the end of semester test, especially in listening to native speakers and audio lessons?

How I feel about this, I will use photographs to illustrate my feelings. This photo illustrates the metaphor of when I was confused about the end of semester test questions. Here is an image that shows an empty wall. For example, when I listen to native speakers and audio, I can't catch the contents of the discussion delivered by native speakers and audio because I feel confused and can't understand what the native speaker or audio is saying. (Student MN) 


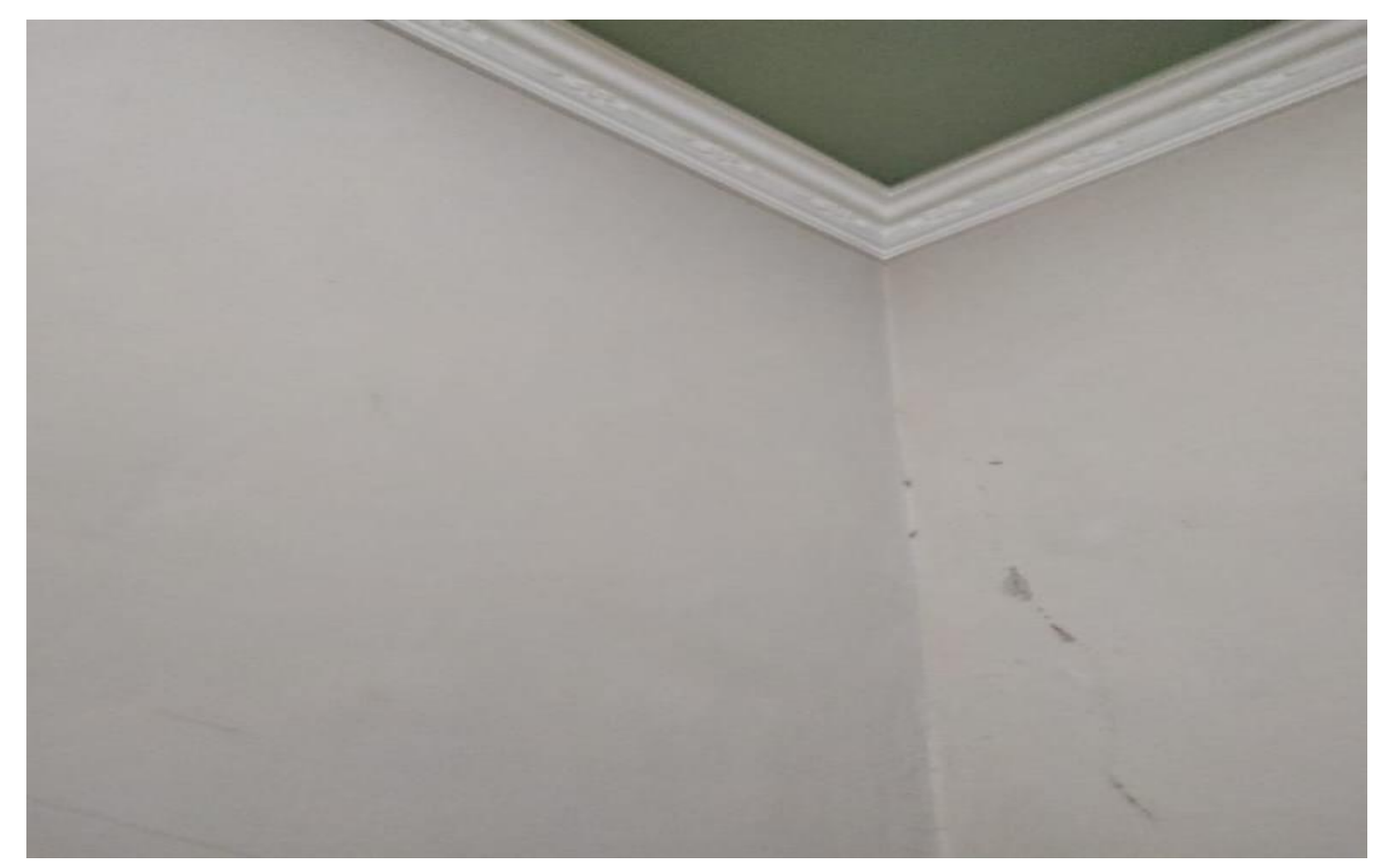

Figure2. Photographs of empty wall

\section{My condition is like a fan when listening to native speakers and English audio}

For some people listening is one of the language skills among the four language skills other language skills such as writing, reading, and speaking. Activities listening are important in developing someone's language skills. Listening is very close to its meaning by hearing and listening. However, if we go further, the three words have differences in understanding. Many people still do not understand the difference. Moreover, AWM (Figure 3) speakers will share their experiences of conditions they experienced when listening to native speakers and audio, who comment as follows:

So, to be honest I really don't master English skills at all and I entered the English department because of the wishes of my parents, so the conditions during class or exams I illustrate like a fan because, the fan just sits or stands like there is no burden, sighed like myself who when I didn't know anything could only be kept quiet and sighed so hard with a speed of 123 and yes... like a fan depending on how heavy the situation is, and the last one the fan can only turn to the right and left at one time like me when 
I don't understand native speakers said or when understanding the audio that was playing during the listening test (student AWM).

As a person who is not a native English speaker who grew up in an environment that does not use English as a language of instruction and communication, you may find it difficult to practice listening to English well. Many think that this listening practice is very difficult to do, especially when listening to native speakers, which you might think is very fast. Not only that, maybe you can lose your confidence when trying to digest the meaning of the English conversation spoken by them. Yes, the point is English learners listen to their conversation, it will be difficult. AWM also experiences problems in listening to native speakers and audio:

In the picture that I illustrated, like the propeller on a fan which when turned on will always spin fast, even though I don't understand English, I still try to rack my brain to keep thinking how to overcome this, one of which is by learning, learning to understanding native speakers and audio is also not easy, there are a lot of problems and difficulties that occur if suddenly the fan lights go out without electricity or batteries, just like me, who can't get excited from my parents because of the lack of parental attention to me even though it is the main key besides myself is the will, but maybe my parents' love is poured into prayer, hopefully so, sometimes my mental condition also decreases because I'm too afraid to face the course, I feel like I'm depressed and seem unpleasant, and I'm also too lazy to practice outside class hours I think too I'm tired of doing it, other obstacles like me are also difficult to understand the material, not comfortable with a class that is too crowded so it's hard to focus on understanding or listening to native speakers (students AWM).

This, of course, needs to be trained, so that your listening skills will develop. It is not easy, but if you know the tips everything will become easier.

1. Learn Different Types of Accents.

In Indonesia, not many people can learn English directly with Caucasians. So, we are used to hearing English with an Indonesian accent. This results in when we hear native speakers speak, many of their words are difficult to 
understand. Therefore, it is better to learn the accents commonly used by native speakers when learning English. Examples include American accents and British accents. If you are familiar with the accent, of course it will not be difficult when you speak directly with native speakers.

2. Recognizing Reduced Forms.

Of course, when speaking daily, the average person uses informal language. It is different when writing, especially for academic needs, of course, the formal or standard language used. This also applies to English. Usually, native speakers use reduced forms when speaking casually. Reduced forms are formed when people speak quickly, eliminating several words and combining several words into one. Example: (1) Want to = Wanna, (2) Going go = Gonna., (3) Don't know = Dunno., (4) Gotto = Gotta.

3. Learn to Ignore Fillers.

Filers are general words that are not important and do not add too much importance to a sentence. Usually, native speakers use fillers just as a habit. When native speakers speak, you can try ignoring the fillers they use. So, you will focus more on the main point of the sentence expressed. Example of Fillers: Anyways, Basically, By the way, I mean, obviously, well, you know. 4. Preparing the Conversation.

If possible, you can prepare a conversation about what you would like to discuss with a native speaker. It can be started by preparing questions, arguments, responses, and more. Of course, in real situations, you will still improvise. But by preparing the topic beforehand, you will be better prepared and learn any related vocabulary.

5. Study with Subtitles

The next tip that is no less important for you to do is to learn English with subtitles. When you hear someone speak and see the English writing, it will really help you to know how to pronounce the word correctly. You can try watching YouTube, which uses subtitles or watching movies and tv 
shows, it can also be a reference to understand the speaking style of native speakers better.

6. Do not be shy about asking for repetition

Often native speakers do not realize they speak too fast or even assume that you will understand everything they are saying. So, they will talk as usual, and those who are still in the learning stage will be confused about it.

One principle that must be instilled is not to be shy. Native speakers will certainly understand if you are honest. Never be shy about asking them to repeat what was said, asking them to speak a little slower, and maybe even asking them to spell a difficult word. Do not pretend you understand.

\section{Consistent}

Whatever it is, the key is to be consistent. Especially when it comes to learning the language, you cannot study 24 hours a day and you will be smart forever. The long duration of time but rarely done is not very good compared to the small but often repeated duration of learning. Pay close attention to how native speakers speak on any platform. If you can speak face-to-face, make the most of it.

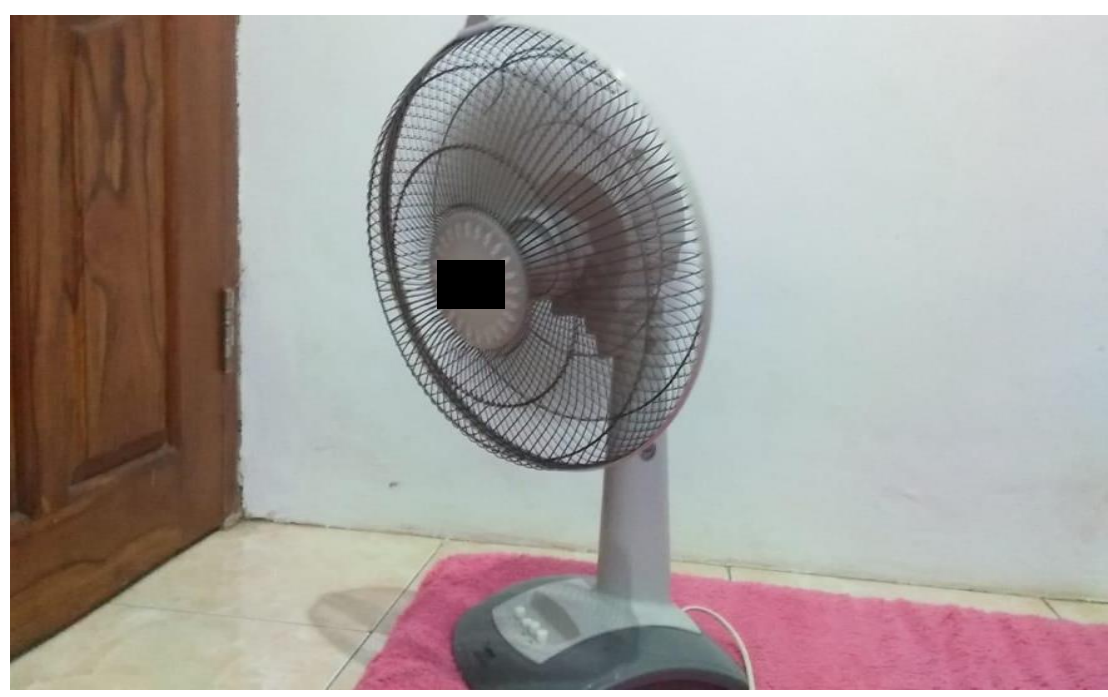

Figure3. An illustrated of fan photo. 


\section{My feeling of listening to native speakers is like my food}

The photo I was sharing was a meal in a jar. This picture describes me when listening to native speakers and audio. This photo explains a food that looks different between the outside and the inside. As I looked on the outside, the food looked round and long, but when I opened the lid and looked inside it, it was different, inside the food jars were some Fried crackers. This is how I feel when learning native speakers and audio. When I listen to a stranger speak English, I understand a word he says, but I don't understand what the word means (Student LIA)

The reason I do not understand the meaning of words spoken by foreigners because I have not improved my vocabulary much. English major had to be diligent in adding to the English vocabulary. In addition to the English vocabulary, I had to memorize it. Some steps must be taken to learn by heart the English vocabulary: using apps or games, using the mnemonic method, making flash CARDS, drawing/visual, reading a book, making a sentence, engaging in conversation, taking small notes, creating an interesting learning atmosphere, breakdown of a word, understanding that vocabulary, repeat several times regularly, use or practice that vocabulary, study and use prefix, focus on the vocabulary required, take it to a higher level.

When we memorize English vocabulary, we must also memorize its meaning to know and understand native speakers and audio. In addition to the benefits of memorizing the meaning and vocabulary are many, such as improving IQ, better speaking in English, better reading in English, better acquiring high TOEFL, better acquiring new memories and thoughts, more rational thinking, more open to new cultures, knowing what is in other countries, building confidence, easier on career achievement, and easier to master technology. 


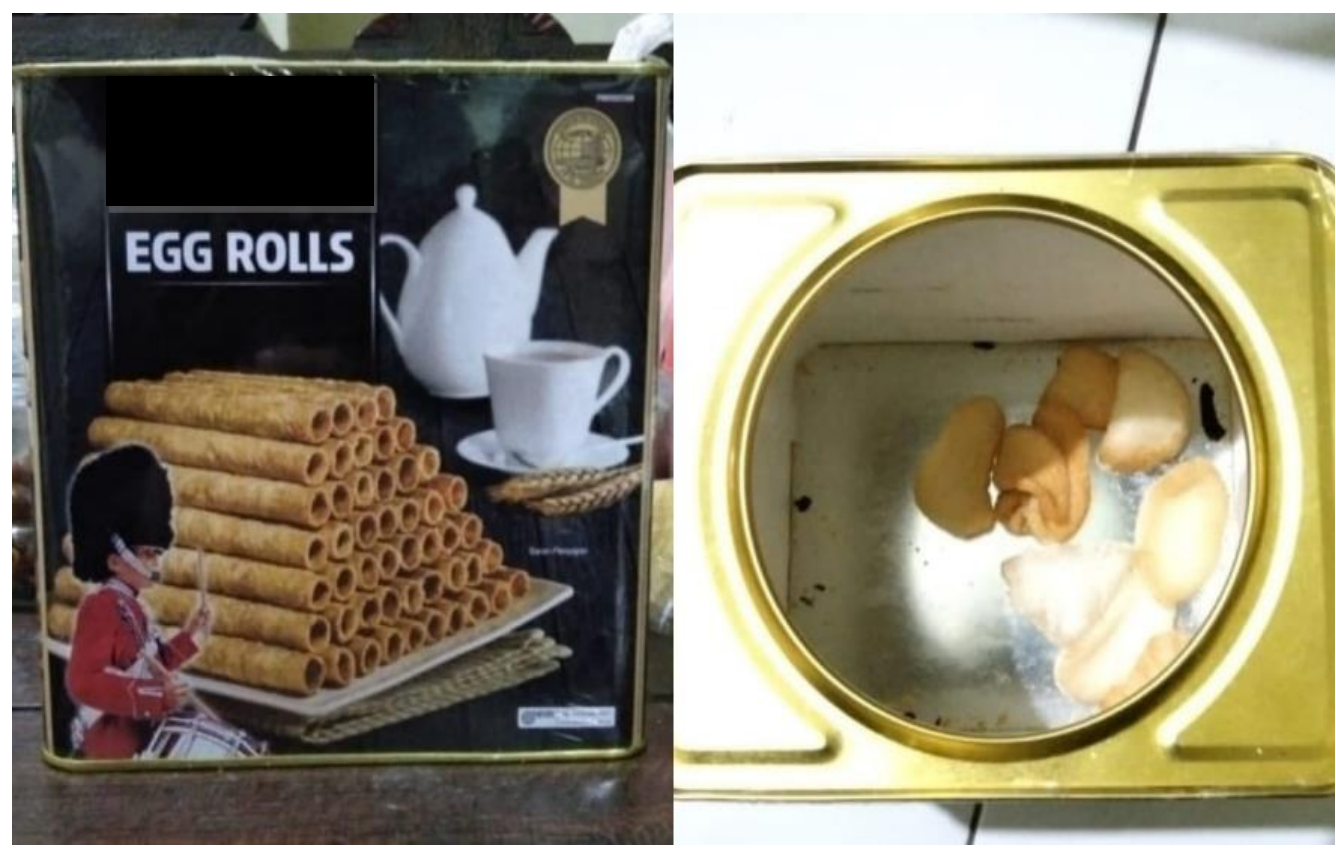

Figure4. The photo of the unconsistency of a food between the outside and the inside.

\section{Discussion}

Listening attempt is described as the planned allocation of scholarly sources to triumph over limitations in intention pursuit while carrying out a listening project. Obstacles to listening may also include outside elements, history noise, inner elements, and language information. Speaking, and listening, the attempt will increase with the importance of the implementation such that greater history noise or poorer information of the goal language ends in more listening attempts, reflecting engagement of cognitive source. Sustained listening attempt normally ends in intellectual fatigue associated with project disengagement and a discounted motivation to make investments and cognitive attempts. However, the connection among listening attempts and fatigue is poorly understood (Brännström et al., 2021).

The enjoyment of full listening is a multidimensional phenomenon. A quantity of research had used subjective ranking to analyze the impact of noise on listening attempts in each adult and child. However, such rankings regularly correlate poorly with extra objective measures of overall 
performance on a dual-mission paradigm or with neurophysiological measures that are alternate in student size. Although subjective rankings can also efficiently seize perceived adjustments in listening attempts inside individuals, they are much less successful at taking pictures variations among characters or groups (McGarrigle et al., 2021).

Based on the image illustration above, we can understand a learning process about how our brain processes understanding a native speaker and audio speakers saying, from this study, we can learn about a learning process in the English education course, especially the lesson about listening, about how to understand the words of native speakers and audio. The role of English as an International language is growing. That is why English has become a learning material in schools around the world. Furthermore, there is a very rapid development right up to now. Basically, there are four important aspects of English that we must always understand. And among these are listening, speaking, writing, and reading. Everyone in understanding the four concepts always has a different level of difficulty. For example, you might find it difficult to communicate, lack grammar, or struggle with grammar. It is difficult to understand native speakers and audio speech. Naturally, English-Speaking abilities, as well as ours, are measured in their listening skills. If we have good listening skills, then we are easier to understand native speakers as well as audio speakers, in addition to his speaking side, we can communicate in English too.

\section{Conclusion}

From the findings of the research above, it can be concluded that. Moreover, this study focuses on the problems experienced by higher education students regarding the words spoken by native speakers, either spoken directly or through audio during learning, and some of the causes. Some students stated that they were very worried about this problem as a student. The first student stated that when she tried to understand what was 
conveyed by the native, she still had a little understanding, but the problem was he felt a lot of confusion in understanding it. She felt that the difference in pronunciation of each country was the leading cause. While the second student said that his understanding of native listening was very minimal, she needed extra hearing to be able to understand English words spoken by native speakers, she also said that the English-speaking environment was a factor supporting the habit of speaking and listening to English, while what happens in society is the opposite, and not as expected. While the third student said that she still did not understand English, when she listened to the native speaker speaks, he could only turn his head to the right and left because she had difficulty understanding it, this happened because she did not study it enough and the class conditions made him uncomfortable to focus on learning listening. Finally, the fourth student said that he could understand the spoken words, but she did not know the meaning of the words, so she could not reach a maximum understanding. Problems like this are common for Indonesian people, especially their students. It is also necessary to evaluate education in Indonesia, especially in learning English, because English is the language used throughout the world, so understanding what native speakers say is very important. This is because if we can understand speech in English, especially native speakers, we will be able to see the wider world.

\section{References}

Arya, V., \& Medgyes, P. (2000). Native and non-native teachers in the classroom. Sytem, $28,355-372$.

Becke, S. D., \& Bongard, S. (2018). Using photo elicitation to introduce a network perspective on attachment during middle childhood. International Journal of Qualitative Methods, 17(1). Retrieved from Article 1609406918797017

Behrendt, M., \& Machtmes, K. (2016). Photovoice as an evaluation tool for student learning on a field trip. Research in Science \& Technological Education, 34(2), 187-203.

Brannstrom, K. J., Rudner, M., Carlie, J., Sahlén, B., Gulz, A., Andersson, K., \& Johansson, R. (2021). Listening effort and fatigue in native and non-native primary school children. Journal of Experimental Child Psychology, 210, 105-203. Retrieved from https://doi.org/10.1016/j.jecp.2021.105203 
Ciolan, L., \& Manasia, L. (2017). Reframing Photovoice to Boost Its Potential for Learning Research. International Journal of Qualitative Methods, 16(1). Retrieved from https://doi.org/10.1177/1609406917702909

Davis, A. (2011). Building comprehension strategies: for the Primary Years. Hong Kong: Eleanor Curtain Publishing.

Esterberg, K. . (2002). Qualitative methods in social research. Boston: McGraw-Hill.

Glaser, B. ., \& Strauss, A. . (1967). The discovery of grounded theory: Strategies for qualitative research. New York: Aldine De Gruyter.

Horii, S., Pham, H. T. T., Dang, T. T. N., Nguyen, C. T. M., \& Amaike, N. (2021). Nurses' perception of individual and organizational changes caused by a novel clinical training system for new graduate nurses: A qualitative research using photovoice. Nurse Education Today, 102(104901). Retrieved from https://doi.org/10.1016/j.nedt.2021.104901

Jackson, D. O., \& Burch, A. R. (2017). Complementary theoretical perspectives on taskbased classroom realities. TESOL Quarterly, 51(3), 493-506. Retrieved from https://doi.org/10.1002/tesq.393

John, L. (2002). English Skills with Readings 9th Edition. Connect Writing.

Kelly, K., Lee, S. H., Bowen Ray, H., \& Kandaurova, M. (2018). Using the photovoice methodology to increase engagement and sharpen students' analytical skills regarding cultures, lifestyles, and markets internationally. . . Marketing Education Review., 28(2), 69-74.

Kotla, B., Bosman, L. B., \& Keller, J. (2021). How photovoice can be used for continuous improvement within an aviation certified flight academic degree program. International Journal of Educational Research Open, 2(2), 100042. Retrieved from https://doi.org/10.1016/j.jedro.2021.100042

Latz, A. ., \& Mulvihill, T. . (2017). Photovoice reserach in education and beyond: A practical guide from theory to exhibition. New York: Routledge.

Maric, M., Penger, S., Todorovic, I., Djurica, N., \& Pintar, R. (2015). Differences in Learning Styles : A comparison of Slovenian Universities. Procedia - Social and Behavioral Sciences, 197(February), 175-183. https://doi.org/10.1016/j.sbspro.2015.07.079

Martinez, E. G., \& Tuesca, R. (2017). learning styles and gross autonomy assessment outcomes at a Colombian School of Medicine, (xx).

McGarrigle, R., Rakusen, L., \& Mattys, S. (2021). Effortful listening under the microscope: Examining relations between pupillometric and subjective markers of effort and tiredness from listening. Psychophysiology, 58(1). Retrieved from https://doi.org/10.1111/psyp.13703

Murray, N. (2011). Ten 'good practice principles' Ten key questions: considerations in addressing the English language needs of higher education students. Retrieved from https://doi.org/10.1080/55538907294360

Richards, J. (2001). Curriculum Development in Language Teaching. Cambridge, UK: Cambridge University Press.

Ronzi, S., Pope, D., Orton, L., \& Bruce, N. (2016). Using photovoice methods to explore older people's perceptions of respect and social inclusion in cities. SSM-Population Health, 16(2), 732-745. Retrieved from https://doi.org/10.1016/j.ssmph.2016.09004 
Saldana, J. (2009). The coding manual for qualitative researchers. Los Angeles: Sage Publications, Inc.

Wass, R., Anderson, V., Rabello, R., Golding, C., Rangi, A., \& Eteuati, E. (2019). Photovoice research methods for higher education research. Retrieved from https://doi.org/10.1080/169279107294360

$\mathrm{Xu}, \mathrm{Z}$. (2018). Exploring English as an international language curriculum, materials and pedagogical strategies. Retrieved from https://doi.org/10.1177/0033688217753848 